\title{
RESISTANCE EXERCISE PROTOCOL DOES NOT CAUSE ACUTE GENOTOXIC EFFECTS IN TRAINED INDIVIDUALS
}

\author{
PROTOCOLO DEEXERCICIO RESISTIDO NÃO PROVOCA EFEITO GENOTÓXICO AGUDO \\ EM SUJEITOS TREINADOS \\ PROTOCOLO DEE EJERCICIO RESISTIDO NO PROVOCA EFECTO GENOTÓXICO AGUDO \\ ENSUJETOSENTRENADOS
}

Original Article

ARTIGO ORIGINAL

Artículo Original

\author{
Nelson João Tagliari \\ (Physical Education Professional) \\ Luciano de Oliveira Siqueira' \\ (Pharmacist) \\ Jorge Frederico Pinto Soares ${ }^{2}$ \\ (Physical Education Professional) \\ Vanusa Manfredini ${ }^{3}$ \\ (Pharmacist) \\ Victor Machado Reis ${ }^{2}$ \\ (Physical Education Professional)
}

1. Universidade de Passo Fundo,

Passo Fundo, RS, Brazil.

2. Centro de Investigação

em Desporto, Saúde \&

Desenvolvimento Humano

(CIDESD), Vila Real, Portugal.

3. Universidade Federal do Pampa,

Uruguaiana, RS, Brazil.

\section{Correspondence}

Nelson João Tagliari. Travessa Wolmar Salton, no 116, apto 701.

Passo Fundo/RS. 99010370.

njtagli@gmail.com/neljoao@upf. br.

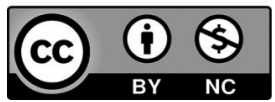

\begin{abstract}
Introduction: Resistance exercise, particularly strength training, has been progressively gaining more and more followers worldwide. Despite a considerable increase in the amount of research and literature available on this topic, resistance training is undergoing important developments. Anaerobic metabolism, which characterizes resistance training, enhances the ischemic process and blood reperfusion, thereby generating reactive oxygen species (ROS). The imbalance between the production of free radicals and antioxidant defenses may induce oxidative stress with subsequent protein oxidation, lipid peroxidation, DNA damage in several cells, and other effects. This process may be intensified at rest because the $\mathrm{O}_{2}$ deficit is counteracted by a process known as excess post-exercise oxygen consumption. Objective: To analyze the effects of ROS in strength training on the DNA of human lymphocyte, biomarkers of lipid damage (TBARS) and metabolism (triglycerides, protein, glycose, albumin and urea). Methods: Comet assay involving a count of 100 cells, which were divided into five classes of damage (no damage $=0$, maximum damage $=4$ ), thereby constituting an indication of DNA damage, and the micronucleus test, where the cell samples were centrifuged at 1000-1500 RPM for ten minutes at room temperature for the micronuclei analysis. Results: An elevation in triglyceride concentrations was observed $5 \mathrm{~h}$ post-exercise $(\mathrm{p}=0.018$ ), probably due to nutrition. There were no significant differences in the other biochemical parameters. In terms of the DNA damage measured by the Comet assay and micronucleus test, no statistical differences were observed until 5h post-exercise. Conclusion: The proposed training session did not cause oxidative or genotoxic damage in trained individuals under the proposed conditions. Level of Evidence II; Prognostic studies-Investigation of the effect of patient characteristics on the disease outcome.
\end{abstract}

Keywords: Resistance training; DNA damage; Genotoxicity; Comet assay.

\section{RESUMO}

Introdução: O treinamento resistido, principalmente a musculação, vem progressivamente ganhando novos adeptos em todo o mundo. Apesar de haver um significativo aumento no número de pesquisas e na literatura disponível sobre o assunto, o treinamento resistido vem passando por um importante processo de evolução. O metabolismo anaeróbico, que caracteriza o treinamento resistido, acentua o processo de isquemia e a reperfusão sanguínea, gerando espécies reativas do oxigênio (ERO). O desequilíbrio entre a produção de radicais livres e as defesas antioxidantes pode desencadear estresse oxidativo e levar, entre outros, à oxidação de proteínas e à peroxidação de lipídios, além de danos no DNA de diversas células. Isso pode ser amplificado durante o repouso, pois o déficit de $\mathrm{O}_{2}$ é reposto por um processo denominado excesso de oxigênio consumido após exercícios. Objetivo: Analisar os efeitos de ERO em um treinamento de musculação sobre - DNA de linfócitos humanos, de biomarcadores de dano lipídico (TBARS) e de metabolismo (triglicerídeos, proteínas, glicose, albumina e ureia). Métodos: Teste Cometa mediante contagem de 100 células, as quais foram classificadas em cinco classes de dano (sem dano =0, dano máximo =4), constituindo, dessa maneira, um índice de dano no DNA e o teste de micronúcleo, no qual as amostras das células foram centrifugadas a 1000-1500 RPM por dez minutos em temperatura ambiente para a análise de micronúcleos. Resultados: Constatou-se elevação das concentrações de triglicerídeos após 5 horas do treinamento $(p=0,018)$, relacionada, provavelmente, à alimentação. Os demais parâmetros bioquímicos não mostraram diferenças significantes. Com relação ao dano provocado no DNA medido pelos testes Cometa e de micronúcleo, não se constatou diferença estatística até 5 horas após o treinamento. Conclusão: A sessão de treinamento proposto não provocou danos oxidativos nem genotóxicos em indivíduos treinados, nas condições propostas. Nível de Evidência II; Estudos prognósticos - Investigação do efeito de característica de um paciente sobre o desfecho da doença.

Descritores: Musculação; Dano ao DNA; Genotoxicidade; Ensaio Cometa.

\section{RESUMEN}

Introducción: El entrenamiento de resistencia, especialmente la musculación viene ganando progresivamente nuevos adeptos en todo el mundo. A pesar de haber un aumento significativo en el número de investigaciones y en la literatura sobre el tema, el entrenamiento de resistencia viene pasando por un importante proceso de evolución. El metabolismo anaeróbico, que caracteriza el entrenamiento de resistencia, acentúa el proceso de isquemia y la 
reperfusión sanguínea, generando especies reactivas de oxígeno (ERO). El desequilibrio entre la producción de radicales libres y las defensas antioxidantes puede desencadenar el estrés oxidativo y llevar, entre otros, a la oxidación de proteínas y peroxidación de lípidos, además de daño en el ADN de diferentes células. Eso puede ser amplificado durante el reposo, para el déficit de $\mathrm{O} 2$ es restablecido por un proceso denominado exceso de oxígeno consumido después de ejercicios. Objetivo: Analizar los efectos de ERO en un entrenamiento de musculación sobre el ADN de linfocitos humanos, de biomarcadores de daño lipídico (TBARS) y de metabolismo (triglicéridos, proteínas, glucosa, albúmina y urea). Métodos: Prueba Cometa a través de un recuento de 100 células, las cuales se clasificaron en cinco clases de daño (sin daño = 0, daño máximo =4), constituyendo así un índice de daño en el ADN y la prueba de micronúcleo, en el cual las muestras de las células fueron centrifugadas a 1000-1500 RPM por diez minutos a temperatura ambiente para el análisis de micronúcleos. Resultados: Se constató elevación de las concentraciones de triglicéridos después de 5 horas del entrenamiento $(p=0,018)$, probablemente relacionada con la alimentación. Los demás parámetros bioquímicos no mostraron diferencias significativas. Con respecto al daño provocado en el ADN medido por las pruebas Cometa y de micronúcleos, no se constató diferencia estadística hasta 5 horas después del entrenamiento. Conclusión: La sesión de entrenamiento propuesto no provocó daño oxidativo ni genotóxico en individuos entrenados, en las condiciones propuestas. Nivel de evidencia ll; Estudios pronósticos - Investigación del efecto de característica de un paciente sobre el desenlace de la enfermedad.

Descriptores: Entrenamiento de Resistencia; Daño del ADN; Genotoxicidad; Ensayo cometa.

\section{INTRODUCTION}

Resistance training may promote the depletion of nutrients and antioxidants that may predispose to injury, to oxidative stress, and impair athletic performance by interfering with energy metabolism. The increase of oxygen consumption as well as the activation of specific metabolic pathways during or after exercise results in the formation of Relative Oxygen Species (ROE). ${ }^{1}$

The sources of ROE during physical exercise can be activated by the phenomenon of ischemia reperfusion, but can also be induced during periods of rest, especially after performing resistance exercises, in which an $\mathrm{O}_{2}$ deficit is observed. . $^{2,3}$

In this type of exercise, ischemia and reperfusion represent a potential source of free radicals. This process also occurs in sports activities of predominantly anaerobic metabolism, in isometric muscle contractions and in high-intensity and short-duration activities. ${ }^{4}$

The blood reperfusion process simultaneously generates other free radicals, such as hydroxyl radical and nitric oxide, which react with each other to form peroxynitrite, a powerful oxidant that decompose into other ROEs, which may react with tyrosine residues to form nitrotyrosine and promote lipid peroxidation and oxidation of proteins, causing damage to the nucleic acid structure (DNA).,54

Resistance training is an integral part of the prescription of physical exercises targeted at improving health. Attention was drawn to this training in a special way when the American College of Sports Medicine (ACSM) recognized the benefits of this type of training. However, very few studies have investigated the frequency of DNA damage in blood cells so far., ${ }^{5,6}$

Bodybuilding is very widespread in the world. For this reason, the purpose of this study was to analyze the degree of lipid and human lymphocyte DNA damage caused by this type of exercise, by analyzing comet and micronuclei tests.

\section{METHOD}

\section{Study design}

This is a cross-sectional analytical clinical trial with 15 individuals between 18 and 35 years of age, undergoing a resistance training session.

\section{Study sample}

The participants were all Caucasian males with a mean age of 23.07 \pm 3.85 years; weight $(\mathrm{kg})$ of $75.74 \pm 7.32$; height $(\mathrm{cm}) 174.2 \pm 5.0$; BMI $24.39 \mathrm{~kg} / \mathrm{cm}^{2} \pm 2.17$, fat percentage of $11.87 \% \pm 5.28$.
All individuals included in the study were bodybuilders, with at least two years of regular and systematized practice for at least three times a week, non-smokers, non-users of drugs or alcoholic beverages.

\section{Experimental protocol}

Prior to the training session, the participants were instructed not to eat foods with antioxidant ingredients such as: fruits and fruit juices in general, chimarrão (traditional drink from Rio Grande do Sul made from a herb containing antioxidant properties), vegetables, as well as any type of supplementation containing antioxidants, that is, all of them were given a list of foods with antioxidant potentials that should not be consumed in the 24 hours preceding the evaluations, through the application of a Food Diary.

Then, the individuals completed a resistance training session in which the thorax agonist/antagonist system was divided into three series of each exercise with the appropriate weights for 10 repetitions in each one. A 60-second recovery interval was established between the sets, totaling a training volume of three exercises for the back and three for the chest with three sets each, alternating the exercises of back and chest, totaling 18 sets.

Blood samples were taken shortly after the end of the training session, five hours after the training and at rest. Five $\mathrm{ml}$ of venous blood were collected aseptically from the volunteers' antecubital fossa. The blood samples were stored in a test tube with specific anticoagulants for each biochemical analysis to evaluate DNA damage, markers of metabolism and oxidative stress.

\section{Biochemical variables}

The comet test was performed by counting 100 cells, which were classified into five classes of damage (no damage $=0$, maximum damage $=4$ ), thus forming a DNA ID, as described by Singh NP, McCoy MT, Tice RR and Schneider EL.?

In the micronucleus test, cell samples were centrifuged at 1000-1500 RPM for ten minutes at room temperature for micronucleus analysis, as described by Schmidt and Sturbelle., ${ }^{8,9}$

For evaluation of lipid peroxidation, the formation of thiobarbituric acid reactive species (TBARS) was measured by means of a heated acid reaction, as described by Esterbauer and Cheesman. ${ }^{10}$

Biochemical analysis for metabolic markers consists in the determination of triglycerides (Trinder method - Labtest ${ }^{\circledR}$ ), Glucose (glucose-oxidase 
method - Labtest ${ }^{\circledR}$ ), Urea (urease method - Labtest ${ }^{\circledR}$ ), total proteins (Biureto method - Labtest ${ }^{\circledR}$ ) according to the manufacturer's execution protocol. After the technical execution, analyte concentrations were determined in a Biosystems BTS $350^{\circledR}$ semiautomatic biochemical analyzer (Biosystems, Barcelona/Spain).

\section{Ethical aspects}

The study was developed according to declarations and guidelines on research involving human beings: Nuremberg Code, Declaration of Helsinki and Resolution No. 196 of October 10, 1996 of the Brazilian National Health Council, and was approved and regulated by the Ethics Committee of the executing institution under Opinion No. 201/2012. The participants signed an Informed Consent Form.

\section{Statistical analysis}

The results are presented in measures of central tendency and measures of dispersion (deviation and standard deviation). The assumptions of normality (Shapiro-Wilk test) and homoscedastic (Levene test) were verified. Confirming the assumptions, analysis of variance (ONE WAY ANOVA) was applied and followed by Tukey's post hoc test to evaluate abnormalities induced by training in the dependent variables.

\section{RESULTS}

The analysis of results does not reveal significant abnormalities related to DNA damage or the remaining biochemical markers analyzed.

Table 1 shows the biochemical parameters, Table 2 presents TBARS results and Table 3 shows the degree of damage and DNA damage index of the individuals tested at rest, post-training and 5 hours after the training session.

Table 1. Results of the biochemical analysis at rest, post-training and 5 hours after the resistance training session.

\begin{tabular}{c|c|c|c|c}
\hline & Pre-training & Post-training & 5 hours after & p value \\
\hline Proteins $(\mathrm{g} / \mathrm{dL})$ & $8.8 \pm 1.4$ & $10.0 \pm 2.6$ & $9.3 \pm 1.5$ & 0.286 \\
\hline Glucose $(\mathrm{mg} / \mathrm{dL})$ & $105.2 \pm 34.6$ & $95.8 \pm 6.8$ & $97.9 \pm 12.5$ & 0.469 \\
\hline Triglycerides $(\mathrm{mg} / \mathrm{dL})$ & $79.6 \pm 32.7$ & $80.3 \pm 40.0$ & $127.8 \pm 71.4$ & $0.018^{*}$ \\
\hline Albumin $(\mathrm{g} / \mathrm{dL})$ & $2.2 \pm 0.5$ & $2.2 \pm 0.1$ & $2.3 \pm 0.4$ & 0.626 \\
\hline Urea $(\mathrm{mg} / \mathrm{dL})$ & $49.5 \pm 12.1$ & $48.3 \pm 12.9$ & $42.5 \pm 13.0$ & 0.281 \\
\hline
\end{tabular}

* Results expressed as mean, standard deviation. ${ }^{*} \mathrm{p}<0.05$ for rest by analysis of the variance test followed by Tukey post hoc test. Source: research data, 2018

Table 2. Lipid peroxidation results measured by TBARS at rest, post-training and 5 hours after the resistance training session.

\begin{tabular}{c|c|c|c|c}
\hline & Pre-training & Post-training & 5 hours after & p value \\
\hline TBARS (nmol) & $0.28 \pm 0.07$ & $0.37 \pm 0.27$ & $0.43 \pm 0.37$ & 0.312 \\
\hline Results expressed
\end{tabular}

Table 3. Analysis of the degree of DNA damage, ID by the comet test and micronucleus test at rest, post-training and 5 hours after the resistance training session.

\begin{tabular}{|c|c|c|c|c|c|}
\hline & & Rest & Post-training & 5 hours after & $p$ value \\
\hline \multirow{6}{*}{ 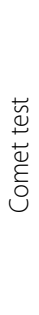 } & Grade 0 damage & $86.87 \pm 1.81$ & $87.27 \pm 1.71$ & $88.07 \pm 1.53$ & 0.15 \\
\hline & Grade 1 damage & $12.13 \pm 2.42$ & $11.40 \pm 1.59$ & $10.80 \pm 1.74$ & 0.18 \\
\hline & Grade 2 damage & $1 \pm 1.07$ & $1.13 \pm 0.99$ & $1.07 \pm 0.18$ & 0.93 \\
\hline & Grade 3 damage & - & $0.07 \pm 0.26$ & $0.07 \pm 0.26$ & - \\
\hline & Grade 4 damage & - & - & - & - \\
\hline & ID comet test & $14.13 \pm 1.73$ & $13.87 \pm 2.29$ & $13.13 \pm 1.73$ & 0.35 \\
\hline \multicolumn{2}{|c|}{ Micronucleus test } & $3.67 \pm 0.72$ & $2.93 \pm 1.28$ & $2.87 \pm 0.92$ & 0.06 \\
\hline
\end{tabular}

* Results expressed as mean \pm standard deviation. ${ }^{* *} p<0.05$ for rest by ANOVA ONE WAY analysis. Source research data, 2018

\section{DISCUSSION}

The biochemical parameters of the metabolism analyzed showed that the protein did not change significantly, although it presented a small post-training increase. Protein synthesis is decreased during the exercise itself, but after exercise, there is a compensatory phenomenon, in which protein turnover appears to be stimulated. Acute resistance training can increase the volume of protein in the muscles for up to 48 hours after completion of exercise. ${ }^{11-14}$

The analysis of protein metabolism and proteolysis measured by the concentration of total proteins, albumin and urea showed no significant variations. The study shows a small reduction of post-training urea and a slightly greater reduction five hours after the training session, suggesting that exercise had an inhibitory effect on proteolysis, lower muscle protein depletion, as the concentration of nitrogen residues in the plasma is indicative of muscle protein degradation. The result found is consistent with those of the study by Pacobahyba et al., ${ }^{15}$ of Uchida et al. ${ }^{16}$ and Carvalho et al. ${ }^{17}$

Glucose concentration analysis showed no statistically significant difference between the samples. The small reduction presented may be related to its use during exercise in the post-training recovery period..$^{18-20}$

Triglycerides showed a statistically significant increase between the determination performed at rest and that performed 5 hours after the training session. Such increase is related to a limitation of this study: the fact that the experimental protocol was performed in the morning, and the athletes had their lunch between the post-training collection and the collection 5 hours later. These results corroborate the fact that the post-training value analyzed does not present any difference compared to the pre-training value..$^{21,22}$

The TBARS measurement of the analyzed sample shows a $57 \%$ increase in lipid damage after 5 hours compared to the damage observed at rest. However, the statistical analysis of the results does not show any significant difference due to the participants' individual response, which could suggest that the proposed experimental protocol may have caused lipid damage at different intensities in the individuals, based on the antioxidant status of each participant. ${ }^{23-26}$

Analysis of genotoxicity measured by the comet test shows more than $86 \%$ of grade zero damage, indicating that the vast majority of the cells analyzed by the test is preserved, that is, without any DNA damage. Analysis of grade 1,2 and 3 damage as well as ID, as measured by the comet test, showed no significant difference, probably because the sample consisted of trained individuals and the exercises applied were familiar to them. Because they exercise regularly, the antioxidant system of these individuals is likely to have undergone adaptations that allow them to perform this type of exercise without any significant oxidative damages.

The results of this study are consistent with the findings of Pavão et al., Kim et al., Rahimi, and Gray et. al., who examined the effect of resistance exercise (bodybuilding) on DNA damage. ${ }^{27-30}$

No grade 4 damage was found, suggesting that the training protocol applied did not induce any relevant genotoxic damage. It is important to emphasize that the study reveals that DNA damage does not prevent that, when necessary, more than one training session per day can be performed, provided that the intensity and volume of training prescribed in this study is respected.

\section{CONCLUSION}

The analysis of results allows to conclude that the resistance training session applied did not induce lipid peroxidation or DNA damage of lymphocytes upon analysis of the comet and micronucleus test in the conditions proposed in this study.

All authors declare no potential conflict of interest related to this article 
AUTHORS' CONTRIBUTIONS: Each author made significant individual contributions to this manuscript. NJT (0000-0002-9031-5481)*: writing of the article, revision and performance of the sampling and application of the training protocols implemented for the research project; LOS (0000-0002-0415-2226)*: blood sampling, data analysis, revision of the article, intellectual concept of the article and creation of the entire research project; VMR (0000-0002-4996-1414)*: statistical analysis, revision of the article, intellectual concept of the article and creation of the entire research project; Jorge Frederico PS (0000-0002-1447-2872)*: revision of the article; VM $(0000-0002-9622-7861)^{*}$ : analysis of all the material collected. *ORCID (Open Researcher and Contributor ID).

\section{REFERENCES}

1. Halliwell B, Gutteridge JMC. Free Radicals in Biology and Medicine. 5th edition. Oxford: Oxford University Press; 2015.

2. Petry ÉR, Alvarenga ML, Cruzat VF, Tirapegui J. (2010). Exercício físico e estresse oxidativo: mecanismos e efeitos. R Bras Ci Movi. 2010;18(4): 90-9

3. Finaud J, Lac G, Filaire E. Oxidative stress. Sports Med. 2006;36(4):327-58

4. Cruzat VF, Rogero MM, Borges MC, Tirapegui J. Aspectos atuais sobre estresse oxidativo, exercícios físicos e suplementação. Rev Bras Med Esporte. 2007;13(5):336-42.

5. Halliwell B, Gutteridge JM. Free radicals in biology and medicine, $4^{\text {th }}$ ed. Mansfield, MA: Oxford Bioscienc; 2006

6. Bloomer RJ, Smith WA. Oxidative stress in response to aerobic and anaerobic power testing: influence of exercise training and carnitine supplementation. Res Sports Med. 2009;17(1):1-16

7. Singh NP, McCoy MT, Tice RR, Schneider EL. A simple technique for quantitation of low levels of DNA damage in individual cells. Exp cell res. 1988;175(1):184-91.

8. Schmidt W. The micronucleus test. Mutat Res. 1975;31(1):9-15.

9. Sturbelle RT, Pinho DSD, Restani RG, Oliveira GRD, Garcias GDL, Martinoroth MDG. Avaliação da atividade mutagênica e antimutagênica da Aloe vera em teste de Allium cepa e teste de micronúcleo em linfócitos humanos binucleados. Rev bras farmacogn. 2010;20(3):409-15.

10. Esterbauer $H$, Cheesman KH. Determination of aldehydic lipid peroxidation products: MDA and hydroxymonenal. In: Parcker L, Glazer A, eds. Methods of Enzymology, vol. 186. New York: Academic Press; 1991. p. 407-21.

11. Foschini D, Prestes J, Charro AM. Relação entre Exercício Físico, Dano Muscular e Dor Muscular de Início Tardio. Revista Brasileira de Cineantropometria e Desempenho Humano. 2007;9(1):101-6.

12. Foureaux G, Pinto KMDC, Dâmaso A. Efeito do consumo excessivo de oxigênio após exercício e da taxa metabólica de repouso no gasto energético. Rev Bras Med Esporte. 2006;12(6):393-8.

13. Hawley JA. Molecular responses to strength and endurance training: Are they incompatible? This paper article is one of a selection of papers published in this Special Issue, entitled 14th International Biochemistry of Exercise Conference-Muscles as Molecular and Metabolic Machines, and has undergone the Journal's usual peer review process. Applied Physiology, Nutrition, and Metabolism. 2009;34(3);355-61.

14. Arciero PJ, Baur D, Connelly S, Ormsbee MJ. Timed-daily ingestion of whey protein and exercise training reduces visceral adipose tissue mass and improves insulin resistance: the PRISE study. J Appl Phys. 2014;117(1):1-10.

15. Pacobahyba N, Vale RGS, de Souza SLP, Simão R, Santos E, Dantas EHM. Força muscular, níveis séricos de testosterona e de ureia em jogadores de futebol submetidos à periodização ondulatória. Rev Bras Med Esporte. 2012;18(2):130-33.
16. Uchida MC, Bacurau RFP, Navarro F, Pontes Jr FL, TessutiVD, Moreau RL, et al. Alteração da relação testosterona: cortisol induzida pelo treinamento resistido em mulheres. Rev Bras Med Esporte. 2004;10(3): 165-8.

17. Carvalho APPF, Molina GE, Fontana KE. Creatine supplementation associated with resistance training does not alter renal and hepatic functions. Rev bras med esporte. 2011;17(4):237-41.

18. Maruoka H, Komaki K, Inoue K. Effects of muscle stress on oxidative stress. J Phys Ther Sci. 2007;19(4):273-6.

19. Silveira LR, Hirabara SM, Lambertucci RH, Leandro CV, Fiamoncini J, Pinheiro CH, et al. (2008). Regulação metabólica e produção de espécies reativas de oxigênio durante a contração muscular: efeito do glicogênio na manutenção do estado redox intracelular. Rev bras med esporte. 2008;14(1):57-63.

20. da Costa Santos NM, Pires JV, Nunes JC, Navarro F. Estudo comparativo do comportamento glicêmico em exercício aeróbio e de força em indivíduos fisicamente ativos e condições do dia a dia. Revista Brasileira de Nutrição Esportiva. 2009;3(18):501-7.

21. Roberts CK, Katiraie M, Croymans DM, Yang $\bigcirc 0$, Kelesidis T. Untrained young men have dysfunctional HDL compared with strength-trained men irrespective of body weight status. J Appl Physiol. 2013;115(7):1043-9.

22. Sheikholeslami VD, Ahmadi KGF. Changes in antioxidant status and cardiovascular risk factors of overweight young men after six weeks supplementation of whey protein isolate and resistance training. Appetite. 2012;59(3):673-8.

23. Valado A, Pereira L. Exercício anaeróbio, óxido nítrico e peroxidação lipídica. Rev Port Ciências Biomédicas. 2009; 4(4):18.

24. Serravite DH, Perry A, Jacobs KA, Adams JA, Harriell K, Signorile JF. Effect of whole-body periodic acceleration on exercise-induced muscle damage after eccentric exercise. Int J Sports Physiol Perform. 2014; 9(6):985-92.

25. Vincent HK, Bourguignon C, Vincent KR. Resistance training lowers exercise-induced oxidative stress and homocysteine levels in overweight and obese older adults. Obesity. 2006;14(11):1921-30.

26. Rech A. Avaliação do processo de recuperação muscular, através da ultrassonografia e de marcadores de estresse oxidativo, após dano induzido por uma sessão aguda de exercício concorrente em ratos machos Wistar. Trabalho de Conclusão de curso. Porto Alegre: Universidade Federal do Rio Grande do Sul; 2011.

27. Pavão PRG, Gontijo ÁMDMC, Ribeiro DA, Salvadori DMF. (2007). Ausência de efeito genotóxico induzido por esteróides anabolizantes em indivíduos fisiculturistas. Rev Br Educ Fís Esp. 2007; 21 (1):5-10.

28. Kim KS, Paik IY, Woo JH, Kang BY. (2010). The effect of training type on oxidative DNA damage and antioxidant capacity during three-dimensional space exercise. Med Princ Pract. 2010;19(2):133-41.

29. Rahimi, R. (2011). Creatine supplementation decreases oxidative DNA damage and lipid peroxidation induced by a single bout of resistance exercise. J Strength Cond Res. 2011;25(12):3448-55.

30. Gray P, Chappell A, Jenkinson AM, Thies F, Gray SR. Fish oil supplementation reduces markers of oxidative stress but not muscle soreness after eccentric exercise. Int J Sport Nutr Exerc Metab. 2014; 24(2):206-14 